UDC 630.1:630.4

ЗАХИСТ ЛІСУ

https://doi.org/10.33220/1026-3365.133.2018.119

O. Y. ANDREIEVA

\title{
CLIMATIC FACTORS INFLUENCING THE VULNERABILITY OF SCOTS PINE TO BARK BEETLES ATTACKS IN THE CENTRAL POLISSYA
}

Zhytomyr National Agroecological University

\begin{abstract}
The aim of the research was to evaluate the changes of climate factors in Central Polissya, which can contribute to Scots pine vulnerability to bark beetle attacks and increase of their population density. In 2005-2018 an average annual and growing season air temperature increased, especially in the southern part of the region. On temperature conditions until 2009, multivoltine bark beetles were possible to develop only one full generation. Thermal conditions in Scots pine stands in the vicinity of 5 meteorological stations in 2010, three meteorological stations in 2012, two meteorological stations in 2015, one meteorological station in 2016, and five meteorological stations in 2018 were favorable for the development two bark beetle generations. Average growing season precipitation for 2005-2018 was inferior to the long-term data for all analyzed meteorological stations, except Olevsk. Average G. T. Selyaninov hydrothermal index value fell to the Forest-steppe "standard" in 2005 and 2009 and to the Steppe "standard" in 2015. Such a decrease is unfavorable for forest trees, which are adapted to the high humidity of air and soil.
\end{abstract}

K e y w o r d s : forest decline, bark beetles, air temperature, precipitation, G. T. Selyaninov hydrothermal index.

Introduction. Climatic conditions of Central Polissya, in general, are favorable for Scots pine (Pinus sylvestris L.). However, pine stands decline is progressing in the region since the beginning of this decade (Borodavka et al. 2016, Meshkova \& Borysenko 2017, 2018, Andreieva et al. 2018, Andreieva \& Goychuk 2018, Vyshnevskyi \& Turko 2018).

Similar processes are recorded in other regions of Europe (Siitonen 2014, Lieutier et al. 2016, Pineau et al. 2017). They are often explained by climate change (Balabukh et al. 2013, Getmanchuk et al. 2017, Shvydenko et al. 2018) and considerable anthropogenic impact (Meshkova \& Borysenko 2018, Sazonov et al. 2017).

Climatic factors have a direct and indirect impact on forest tree species distribution, growth (Vorobyov 1953), and their vulnerability to different unfavorable abiotic and biotic factors, including insect pests (Meshkova 2009). Therefore, the increase of bark beetle foci area is connected with an increase of forest susceptibility and tolerance to damage, change in a microclimate of some plots due to anthropogenic influence, as well as an acceleration of insects' seasonal development (Meshkova et al. 2017). At the same time, the spread of pine forest decline is not homogeneous even within the same region, which is connected both with relief, climate and soil diversity (Dibrov 1969), as well as with different availability of preferable forest plots for colonization (Meshkova \& Borysenko 2018).

In declining Scots pine stands of Central Polissya engraver beetle Ips acuminatus (Gyllenhal, 1827) and six-toothed bark beetle Ips sexdentatus (Boerner, 1767) (Curculionidae, Scolytinae) are the most spread, due to their ability to develop in several generations per year depending on weather conditions (Andreieva et al. 2018).

The aim of the research was to evaluate the changes of climate factors in Central Polissya, which can contribute to Scots pine vulnerability to bark beetle attacks and increase of their population density.

Materials and Methods. Investigations included a statistical and comparative analysis of climate indices, which were evaluated using long-term values of air temperature and precipitation from database https:/climate-data.org and respective values for 2005-2018 from http://rp5.ua.

Six meteorological stations were chosen for analysis: Olevsk, Ovruch, Korosten, Teteriv, Novograd-Volynskij, and Zhytomyr (Table 1).

Annual air temperature, growing season temperature, the sum of positive temperatures for growing season, growing season precipitation and G. T. Selyaninov hydrothermal index (HTI) were evaluated for long-term data and data for 2005-2018. 
G. T. Selyaninov hydrothermal index (Selyaninov 1937) was calculated by the formula (1):

$$
H T I=10 \times \frac{\sum P}{\sum t},
$$

where $\Sigma P$ is precipitation for a period with mean month air temperature over $10^{\circ} \mathrm{C}, \mathrm{mm}$;

$\Sigma t$ is the sum of daily air temperature for the same period, ${ }^{\circ} \mathrm{C}$.

Meteorological stations selected for analysis

\begin{tabular}{|l|c|c|l|}
\hline \multicolumn{1}{|c|}{$\begin{array}{c}\text { Meteorological } \\
\text { station }\end{array}$} & Latitude, N & Longitude, E & \multicolumn{1}{|c|}{ Nearest Forest Enterprises } \\
\hline Olevsk & $51^{\circ} 19^{\prime}$ & $28^{\circ} 46^{\prime}$ & Olevske FE; Bilokorovitske FE \\
\hline Ovruch & $51^{\circ} 19^{\prime}$ & $28^{\circ} 48^{\prime}$ & Ovrutske FE; Narodytske FE; Slovechanske FE \\
\hline Korosten & $50^{\circ} 57^{\prime}$ & $28^{\circ} 38^{\prime}$ & Korostenske FE; Lugynske \\
\hline Teteriv & $50^{\circ} 41^{\prime}$ & $29^{\circ} 36^{\prime}$ & Malynske FE; Radomyshlske FHE \\
\hline Novograd-Volynskij & $50^{\circ} 34^{\prime}$ & $27^{\circ} 37^{\prime}$ & $\begin{array}{l}\text { Baranivske FHE; Gorodnytrske FE; } \\
\text { Emilchinske FE; Novograd-Volynske EFHE }\end{array}$ \\
\hline Zhytomyr & $50^{\circ} 15^{\prime}$ & $28^{\circ} 39^{\prime}$ & Zhytomyrske FE; Korostyshivske FE \\
\hline
\end{tabular}

Notes: meteorological stations are arranged in order of decreasing latitude; FE - Forest Economy; FHE - Forest \& Hunting Economy; EFHE - Experimental Forest \& Hunting Economy.

Descriptive statistics and correlation analyses were performed with the help of MS Excel (Atramentova \& Utevskaya 2008).

Results and Discussion. In the last 14 years, the average annual air temperature has increased in all parts of the region (Fig. 1).

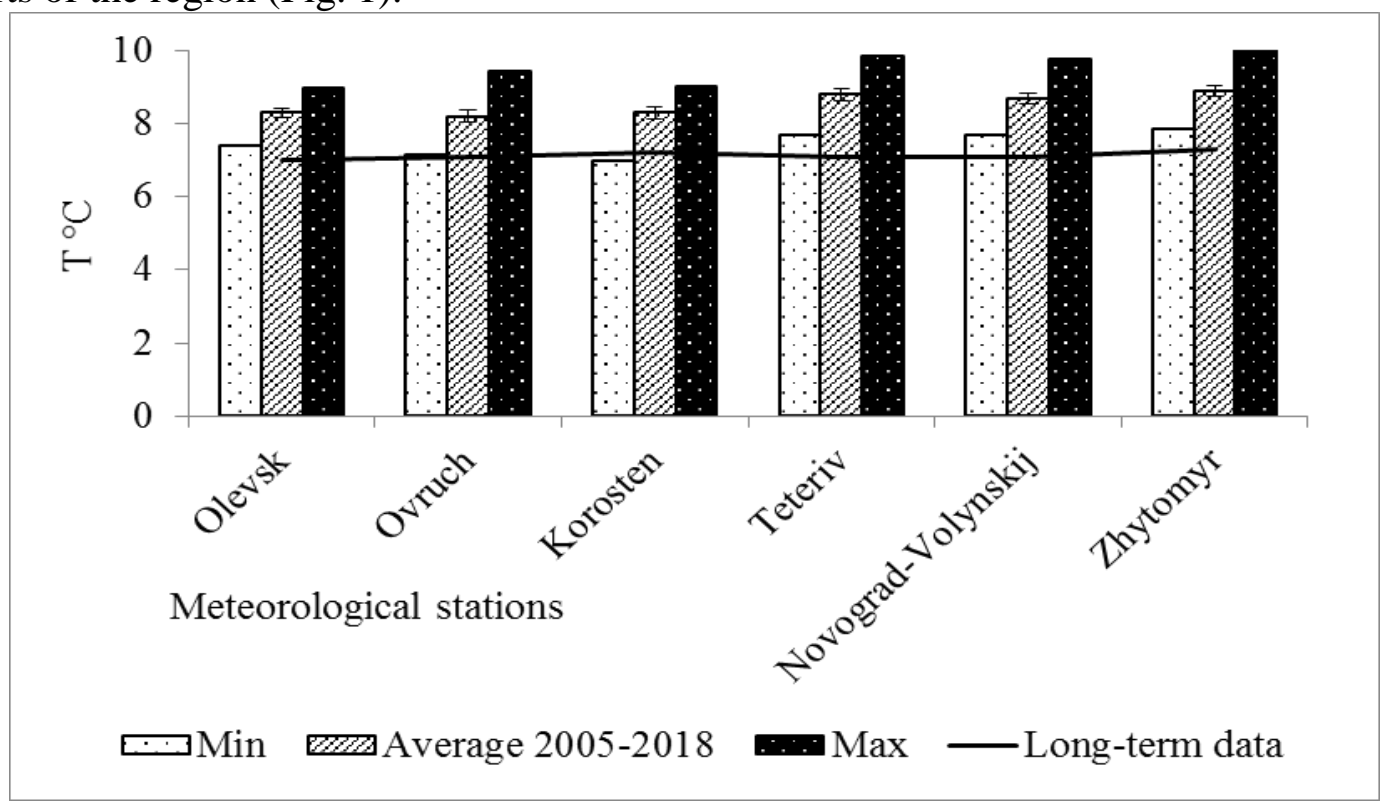

Fig. 1 - Average annual air temperature for 2005-2018 and by long-term data (meteorological stations of Zhytomyr Polissya in order of decreasing latitude)

Such growth was $1.1-1.3^{\circ} \mathrm{C}(15.3-18.6 \%)$ in the northern part of the region, and it reached $1.6-1.7^{\circ} \mathrm{C}(21.9-23.9 \%)$ in the southern part (Table 2). Minimal annual air temperature exceeded long-term values in all analyzed meteorological points, except Korosten, and respective differences with long-term data are the highest in Novograd-Volynskij and Teteriv $\left(8.6\right.$ and $8.3^{\circ} \mathrm{C}$, or 22.5 and $23.9 \%$, respectively).

Average air temperature for the growing season also increased more in the southern part of the region, with the highest difference for Teteriv $-2.46^{\circ} \mathrm{C}$, or $17.3 \%$, respectively (Fig. 2).

However, the minimal value of growing season air temperature was inferior to long-term data in Ovruch and Korosten and was the highest also for Teteriv $\left(1.31^{\circ} \mathrm{C}\right.$, or $\left.9.2 \%\right)$. 
Differences between long-term air temperature and air temperature for 2005-2018 by different meteorological stations of Zhytomyr Polissya

\begin{tabular}{|l|c|c|c|c|c|c|c|c|}
\hline \multirow{3}{*}{ Meteorological station } & \multicolumn{3}{|c|}{ Difference in annual temperature } & \multicolumn{5}{c|}{ Difference in growing season temperature } \\
\cline { 2 - 10 } & $\begin{array}{c}\mathrm{M} 1- \\
\mathrm{L} 1,{ }^{\circ} \mathrm{C}\end{array}$ & $\begin{array}{c}\mathrm{A} 1- \\
\mathrm{L} 1,{ }^{\circ} \mathrm{C}\end{array}$ & $\begin{array}{c}\mathrm{M} 1- \\
\mathrm{L} 1, \%\end{array}$ & $\begin{array}{c}\mathrm{A} 1- \\
\mathrm{L} 1, \%\end{array}$ & $\begin{array}{c}\mathrm{M} 2-\mathrm{L} 2, \\
{ }^{\circ} \mathrm{C}\end{array}$ & $\begin{array}{c}\mathrm{A} 2- \\
\mathrm{L} 2,{ }^{\circ} \mathrm{C}\end{array}$ & $\begin{array}{c}\mathrm{M} 2- \\
\mathrm{L} 2, \%\end{array}$ & $\begin{array}{c}\mathrm{A} 2-\mathrm{L} 2, \\
\%\end{array}$ \\
\hline Olevsk & 0.41 & 1.30 & 5.8 & 18.6 & 0.38 & 1.04 & 2.6 & 7.1 \\
\hline Ovruch & 0.04 & 1.10 & 0.6 & 15.5 & -0.58 & 0.79 & -3.9 & 5.2 \\
\hline Korosten & -0.23 & 1.10 & -3.1 & 15.3 & -0.90 & 0.80 & -6.0 & 5.3 \\
\hline Teteriv & 0.59 & 1.70 & 8.3 & 23.9 & 1.31 & 2.46 & 9.2 & 17.3 \\
\hline Novograd-Volynskij & 0.61 & 1.60 & 8.6 & 22.5 & 0.70 & 1.58 & 4.7 & 10.7 \\
\hline Zhytomyr & 0.54 & 1.60 & 7.4 & 21.9 & 0.68 & 1.65 & 4.5 & 10.9 \\
\hline
\end{tabular}

Notes: meteorological stations are arranged in order of decreasing latitude; A1 - average annual air temperature for 2005-2018; M1 - minimal annual air temperature for 2005-2018; L1 - long-term annual air temperature; A2 average growing season air temperature for 2005-2018; M2 - minimal growing season air temperature for 2005-2018; L2 - long-term growing season air temperature.

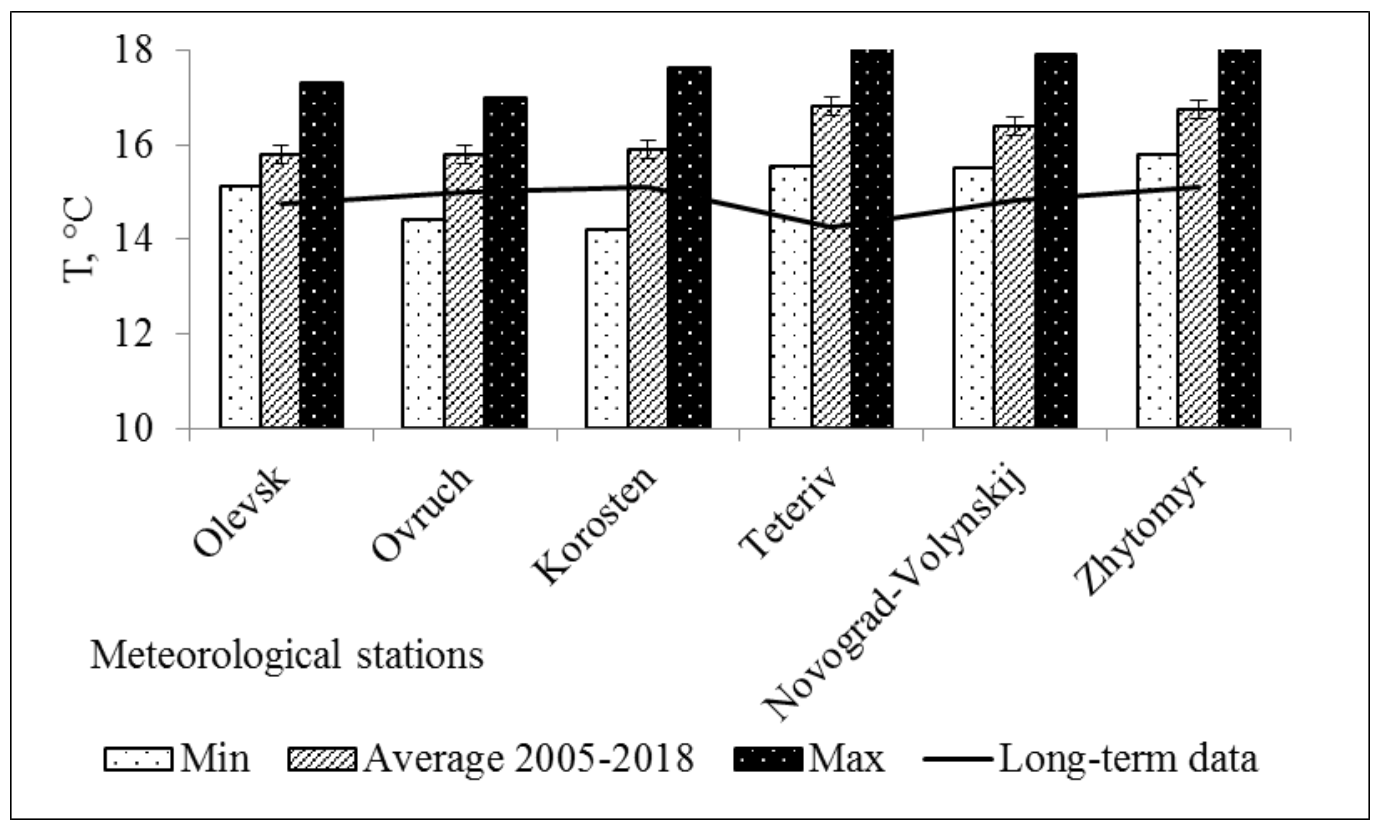

Fig. 2 - Average growing season air temperature for 2005- 2018 and by long-term data (meteorological stations of Zhytomyr Polissya in order of decreasing latitude)

For Olevsk, Ovruch and Korosten the long-term air temperature was exceeded by current data (2005-2018) more for the whole year, than for growing season. For Teteriv exceeding of the longterm data was greater for growing season air temperature, and for Novograd-Volynskij and Zhytomyr, the exceeding of annual and growing season temperature was the same.

For 14 year dynamics of annual air temperature, significant correlation was evaluated for almost all pairs of meteorological stations, except Korosten, which had significant correlation only with Olevsk (Table 3).

Dynamics of annual air temperature for Olevsk significantly correlates with those of all other analyzed meteorological stations, but significance level is lower for neighboring Ovruch and Korosten than for distant Novograd-Volynskij and Zhytomyr. This may be connected with relief features, particularly Ovruch Ridge, which modifies the weather in the surround area (Dibrov 1969).

For dynamics of growing season air temperature, a significant correlation was evaluated for all pairs of meteorological stations, except Ovruch, which had any significant correlation (Table 4). 


\section{ЛICIВНИЦТВО I АГРОЛІСОМЕЛІОРАЦІЯ - FORESTRY AND FOREST МЕLIORATION}

2018. Вип. 133 - 2018. Iss. 133

Sum of positive air temperatures for growing season for 2005-2018 (Fig. 3) was proportional to the average growing season air temperature (see Fig. 2).

Correlation of annual air temperature dynamics by different meteorological stations of Zhytomyr Polissya for 2005-2018

\begin{tabular}{|l|c|c|c|c|c|}
\hline $\begin{array}{c}\text { Meteorological } \\
\text { station }\end{array}$ & Olevsk & Ovruch & Korosten & $\begin{array}{c}\text { Novograd- } \\
\text { Volynskij }\end{array}$ & Teteriv \\
\hline Olevsk & 1 & - & - & - & - \\
\hline Ovruch & $\begin{array}{c}0.58 \pm 0.234 \\
(t=2.49)^{*}\end{array}$ & 1 & - & - & - \\
\hline Korosten & $\begin{array}{c}0.52 \pm 0.246 \\
(t=2.13)^{*}\end{array}$ & $\begin{array}{c}0.24 \pm 0.281 \\
(t=0.84)\end{array}$ & 1 & - & - \\
\hline Novograd- & $\begin{array}{c}\mathbf{0 . 9 4} \pm 0.096 \\
(t=9.77)^{* *}\end{array}$ & $\begin{array}{c}0.57 \pm 0.236 \\
(t=2.43)^{*}\end{array}$ & $\begin{array}{c}0.47 \pm 0.255 \\
(t=1.83)\end{array}$ & 1 & - \\
\hline Volynskij & $\begin{array}{c}\mathbf{0 . 7 5} \pm 0.209 \\
(t=3.60)^{* *}\end{array}$ & $\begin{array}{c}0.53 \pm 0.269 \\
(t=1.96)^{*}\end{array}$ & $\begin{array}{c}0.25 \pm 0.306 \\
(t=0.80)\end{array}$ & $\begin{array}{c}\mathbf{0 . 7 6} \pm 0.206 \\
(t=3.68)^{* *}\end{array}$ & 1 \\
\hline Zheteriv & $\mathbf{0 . 9 0 \pm 0 . 1 2 7}$ & $\begin{array}{c}0.60 \pm 0.230 \\
(t=2.63)^{*}\end{array}$ & $\begin{array}{c}0.40 \pm 0.264 \\
(t=1.52)\end{array}$ & $\begin{array}{c}\mathbf{0 . 9 7} \pm 0.071 \\
(t=13.65)^{* *}\end{array}$ & $\begin{array}{c}\mathbf{0 . 7 9} \pm 0.193 \\
(t=4.09)^{* *}\end{array}$ \\
\hline
\end{tabular}

Notes: * - italic, significant at $P<0.05 ; * *$ - bold, significant at $P<0.01$.

Correlation of growing season air temperature dynamics by different meteorological stations of Zhytomyr Polissya for 2005-2018

\begin{tabular}{|l|c|c|c|c|c|}
\hline $\begin{array}{c}\text { Meteorological } \\
\text { station }\end{array}$ & Olevsk & Ovruch & Korosten & $\begin{array}{c}\text { Novograd- } \\
\text { Volynskij }\end{array}$ & Teteriv \\
\hline Olevsk & 1 & - & - & - & - \\
\hline Ovruch & $\begin{array}{c}0.06 \pm 0.288 \\
(t=0.20)\end{array}$ & 1 & - & - & - \\
\hline Korosten & $\begin{array}{c}\mathbf{0 . 8 9} \pm 0.130 \\
(t=6.88)^{* *}\end{array}$ & $\begin{array}{c}0.06 \pm 0.288 \\
(t=0.21)\end{array}$ & 1 & - & - \\
\hline Novograd- & $\begin{array}{c}\mathbf{0 . 9 4} \pm 0.102 \\
(t=9.18)^{* *}\end{array}$ & $\begin{array}{c}0.12 \pm 0.287 \\
(t=0.41)\end{array}$ & $\begin{array}{c}\mathbf{0 . 8 2} \pm 0.164 \\
(t=5.01)^{* *}\end{array}$ & 1 & - \\
\hline Volynskij & $\begin{array}{c}\mathbf{0 . 8 8} \pm 0.150 \\
(t=5.86)^{* *}\end{array}$ & $\begin{array}{c}0.14 \pm 0.313 \\
(t=0.46)\end{array}$ & $\begin{array}{c}\mathbf{0 . 8 1} \pm 0.186 \\
(t=4.36)^{* *}\end{array}$ & $\begin{array}{c}\mathbf{0 . 9 1} \pm 0.130 \\
(t=7.01)^{* *}\end{array}$ & 1 \\
\hline Teteriv & $\begin{array}{c}\mathbf{0 . 9 2} \pm 0.114 \\
(t=8.04)^{* *}\end{array}$ & $\begin{array}{c}0.15 \pm 0.286 \\
(t=0.51)\end{array}$ & $\begin{array}{c}\mathbf{0 . 7 4} \pm 0.193 \\
(t=3.85)^{* *}\end{array}$ & $\begin{array}{c}\mathbf{0 . 9 5} \pm 0.093 \\
(t=10.23)^{* *}\end{array}$ & $\begin{array}{c}\mathbf{0 . 9 4} \pm 0.108 \\
(t=8.70)^{* *}\end{array}$ \\
\hline
\end{tabular}

Notes: * - italic, significant at $P<0.05 ; * *$ - bold, significant at $P<0.01$.

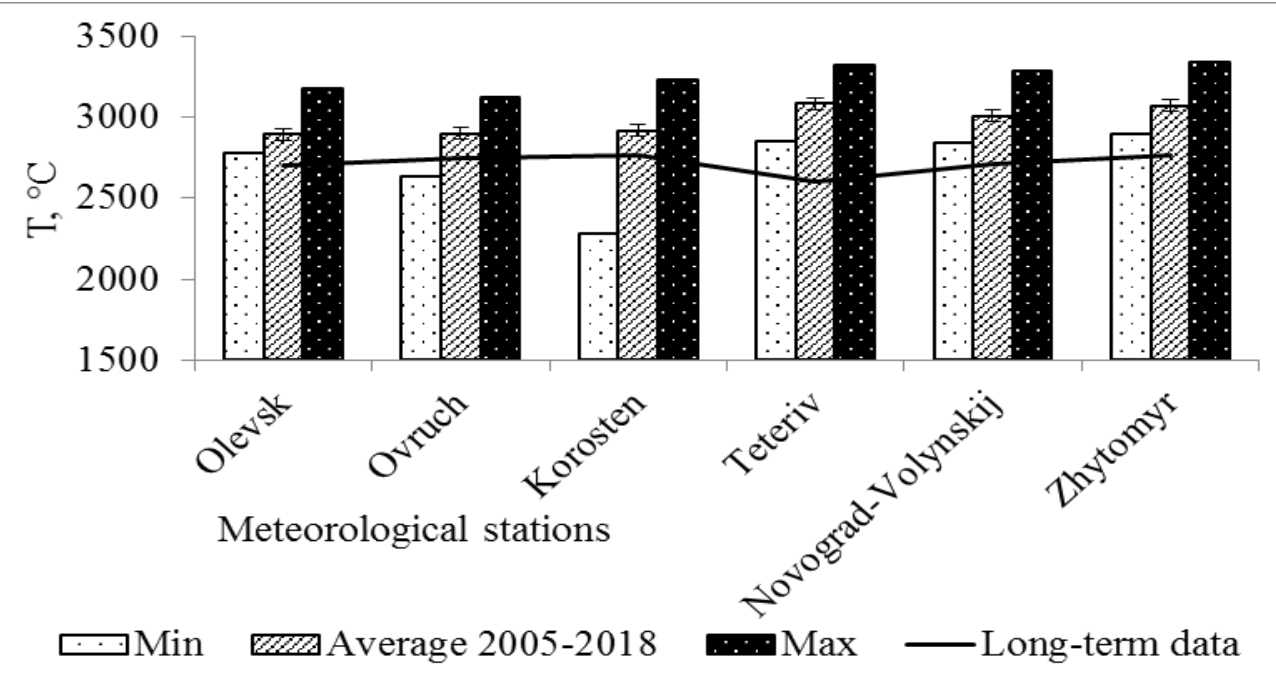

Fig. 3 - Average sum of positive air temperatures for growing season of 2005-2018 and long-term data (meteorological stations of Zhytomyr Polissya in order of decreasing latitude) 
Sum of positive air temperatures for growing season was used for prediction the number of generation for multivoltine bark beetles. As the most abundant in the region Ips acuminatus and Ips sexdentatus demand not more than $1560^{\circ} \mathrm{C}$ for full development (Meshkova et al. 2015), it is possible to evaluate the maximal number of generations per each year. The calculation shows that at the beginning of the analyzed period the sum of positive air temperatures for growing season was enough only for one full generation of bark beetles (Fig. 4).

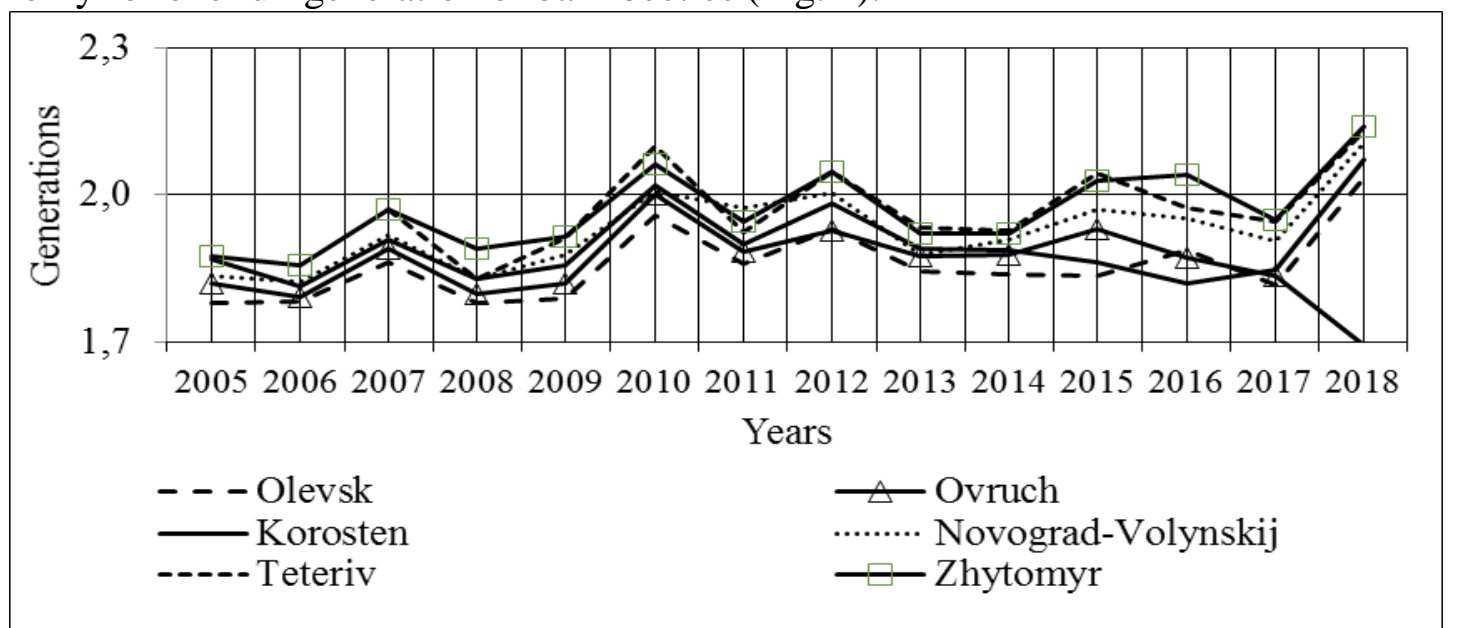

Fig. 4 - Possible number of bark beetle generations evaluated by sum of positive temperatures for 2005-2018 growing seasons (meteorological stations of Zhytomyr Polissya)

However, in 2010 development of two bark beetle generations became possible in all analyzed parts of the region, except Olevsk. The opportunity of two bark beetle generations development in Olevsk appeared only in 2018. It never since 2010 appeared in Ovruch and only twice for this period (in 2010 and 2018) appeared in Korosten. In Novograd-Volynskij development of two full generations of multivoltine bark beetles was possible in 2010, 2012 and 2018, in Teteriv in 2010, 2012, 2015 and 2018, and in Zhytomyr in 2010, 2012, 2015, 2016 and 2018. The years favorable for two bark beetle generations development often coincided for several parts of the region: there were favorable in vicinity of 5 meteorological stations in 2010, three meteorological stations in 2012, two meteorological stations in 2015, one meteorological station in 2016, and five meteorological stations in 2018 (see Fig. 4). In 2018 there is a trend of increasing the sum of positive air temperature for most meteorological stations (and respective increase of bark beetle generation number), except Ovruch with a decrease of growing season air temperature (see Fig. 4). The growth of the bark beetles number which successfully completed their development was registered in outbreak years in the field researches.

Average precipitation for growing season 2005-2018 was inferior to the long-term data for all analyzed meteorological stations (Fig. 5).

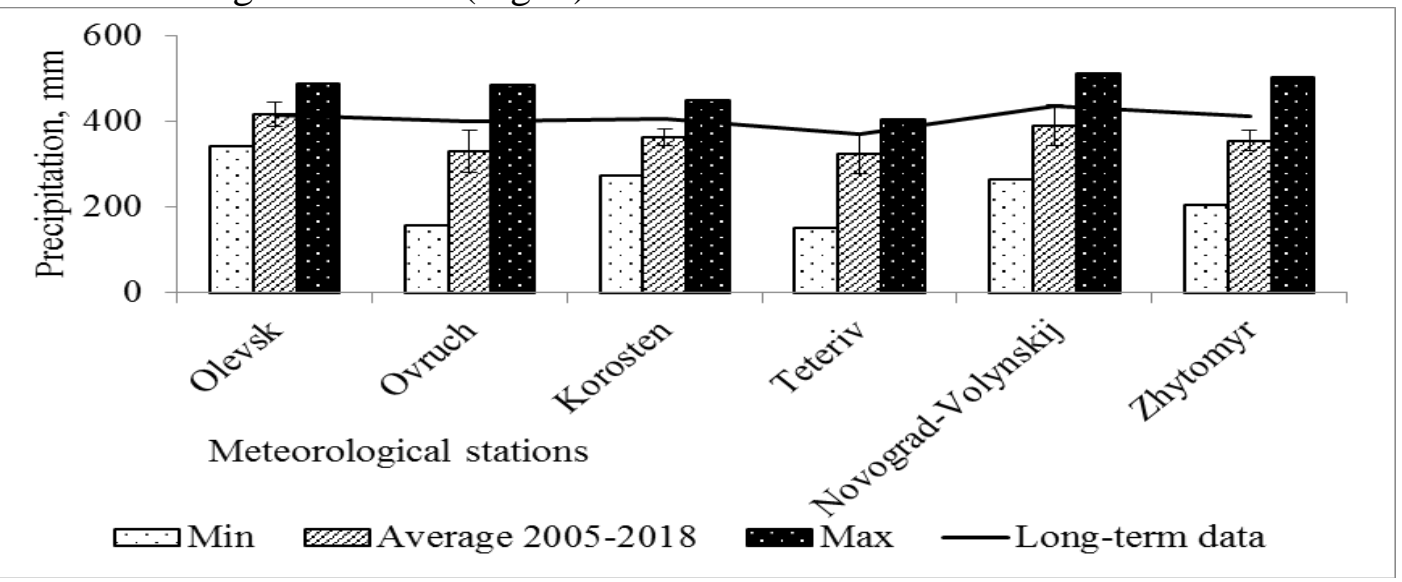

Fig. 5 - Average precipitation for growing season of 2005- 2018 and long-term data (meteorological stations of Zhytomyr Polissya in order of decreasing latitude) 
However, in Olevsk current precipitation exceeded the long-term data by $2.8 \mathrm{~mm}(0.7 \%)$ (Table 5).

Differences between long-term precipitation for growing season and hydrothermal index and respective values for 2005-2018 by different meteorological stations of Zhytomyr Polissya

\begin{tabular}{|l|c|c|c|c|c|c|c|c|}
\hline \multirow{3}{*}{ Meteorological station } & \multicolumn{3}{|c|}{ Difference in precipitation } & \multicolumn{3}{c|}{ Difference in hydrothermal index } \\
\cline { 2 - 10 } & $\begin{array}{c}\text { M1 - L1, } \\
\mathrm{mm}\end{array}$ & $\begin{array}{c}\mathrm{A} 1- \\
\mathrm{L} 1, \mathrm{~mm}\end{array}$ & $\begin{array}{c}\mathrm{M} 1- \\
\mathrm{L} 1, \%\end{array}$ & $\begin{array}{c}\mathrm{A} 1- \\
\text { L1, \% }\end{array}$ & $\begin{array}{c}\text { M2- } \\
\text { L2 }\end{array}$ & $\begin{array}{c}\text { A2 }- \\
\text { L2 }\end{array}$ & $\begin{array}{c}\text { M2 }- \\
\text { L2, \% }\end{array}$ & $\begin{array}{c}\text { A2 }- \\
\text { L2, \% }\end{array}$ \\
\hline Olevsk & 73.0 & 2.8 & 17.6 & 0.7 & 0.09 & -0.28 & 5.8 & -26.2 \\
\hline Ovruch & 85.0 & -69.0 & 21.3 & -17.3 & 0.17 & -0.33 & 11.5 & -22.7 \\
\hline Korosten & 42.0 & -43.1 & 10.3 & -10.6 & 0.11 & -0.24 & 7.8 & -16.5 \\
\hline Teteriv & 34.0 & -47.7 & 9.1 & -12.8 & $\mathbf{- 0 . 1 1}$ & -0.38 & $\mathbf{- 7 . 9}$ & -26.7 \\
\hline Novograd-Volynskij & 76.0 & -43.9 & 17.5 & -10.1 & 0.03 & -0.33 & 2.0 & -20.8 \\
\hline Zhytomyr & 89.0 & -57.8 & 21.5 & -14.0 & 0.14 & -0.33 & 9.6 & -22.1 \\
\hline
\end{tabular}

Notes: meteorological stations are arranged in order of decreasing latitude; A1 - precipitation for growing season for 2005-2018; M1 - maximal precipitation for growing season for 2005-2018; L1 - long-term precipitation for growing season; A2 - HTI for growing season for 2005-2018; M2 - maximal HTI for growing season for 2005-2018; L2 - long-term HTI for growing season.

Maximal precipitation for 2005-2018 exceeded long-term data in all meteorological stations by 42-89 $\mathrm{mm}(9.1-21.5 \%)$. Decrease of precipitation and increase of air temperature brought to decrease of average hydrothermal index value by 0.2-0.4 (by 16.5-26.7 \%) (Fig. 6, see Table 5).

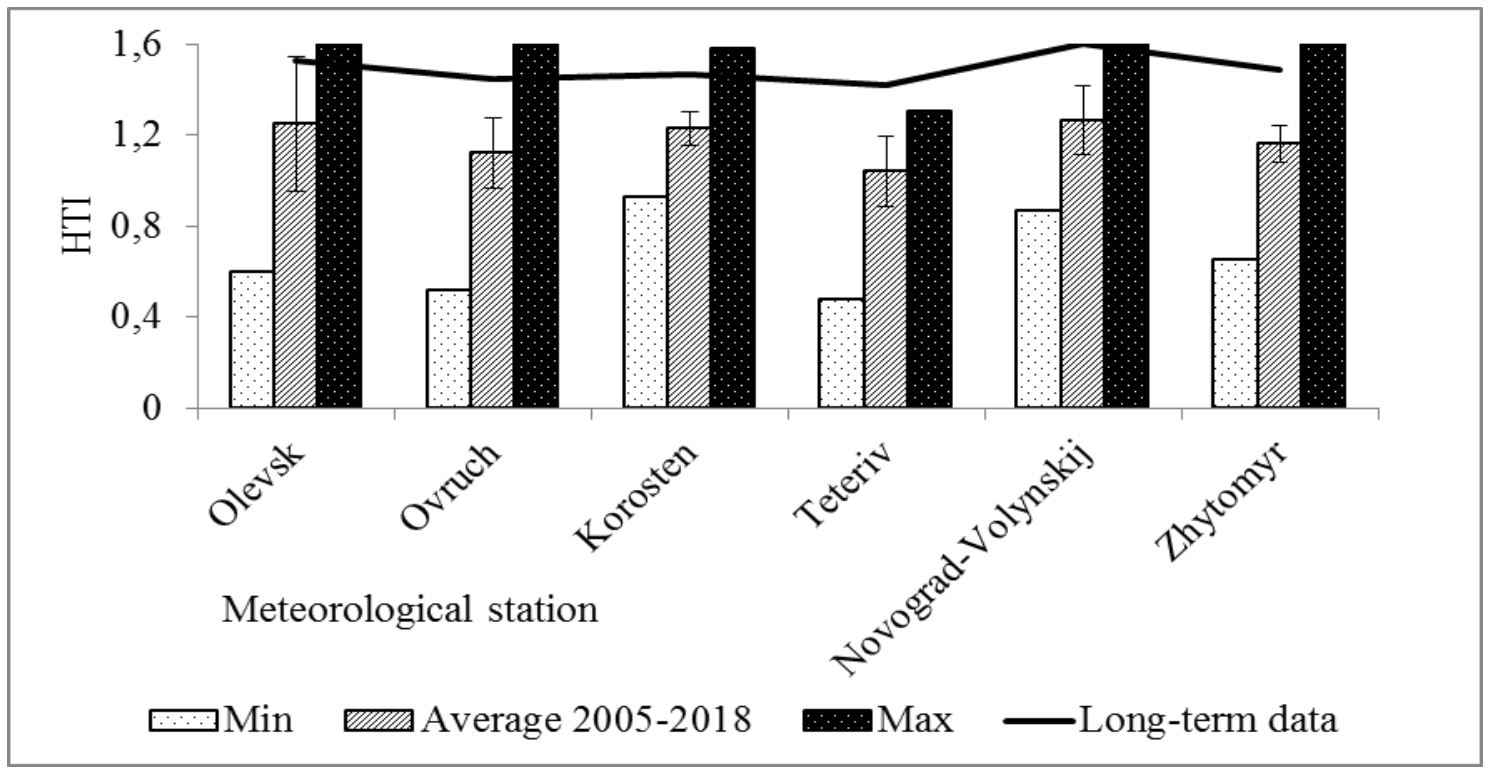

Fig. 6 - Hydrothermal index for growing season of 2005- 2018 and long-term data (meteorological stations of Zhytomyr Polissya in order of decreasing latitude)

The range of hydrothermal index for Polissya was previously evaluated as 1.3-1.6 (Selyaninov 1937). However, only maximal values for 2005-2018 fell into this interval. Average HTI values for this period fell into Forest-steppe "standard" (1-1.3), although the values for Olevsk, Korosten and Novograd-Volynskij are closer to "standard" for Polissya. All minimal values of HTI fell into "standard" for Steppe (0.7-1.0).

Maximal value of the hydrothermal index for 2005-2018 exceeded long-term data by 0.03 ( $2 \%$ ) in Novograd-Volynskij and by $0.09-0.17$ (by 5.8-11.5\%) in Olevsk, Ovruch, Korosten, and Zhytomyr. However, the maximal value of the hydrothermal index for 2005-2018 growing season was inferior to the long-term data for Teteriv by 0.11 (7.9\%) (see Table 5). 


\section{ЛICIВНИЦТВО I АГРОЛІСОМЕЛIОРАЦІЯ - FORESTRY AND FOREST MELIORATION}

2018. Вип. 133 - 2018. Iss. 133

Unlike air temperature, precipitation for individual meteorological stations was absent in the database for some years. Therefore, before analyzing the dynamics of the hydrothermal index, we evaluated correlation coefficients between its values in particular meteorological stations (Table 6).

Table 6

Correlation of hydrothermal index dynamics by different meteorological stations of Zhytomyr Polissya for 2005-2018

\begin{tabular}{|l|c|c|c|c|c|}
\hline $\begin{array}{c}\text { Meteorological } \\
\text { station }\end{array}$ & Olevsk & Ovruch & Korosten & $\begin{array}{c}\text { Novograd- } \\
\text { Volynskij }\end{array}$ & Teteriv \\
\hline Olevsk & 1 & - & - & - & - \\
\hline Ovruch & $\begin{array}{c}\mathbf{0 . 9 6} \pm 0.077 \\
(t=12.5)^{* *}\end{array}$ & 1 & - & - & - \\
\hline Korosten & $\begin{array}{c}0.17 \pm 0.285 \\
(t=0.59)\end{array}$ & $\begin{array}{c}0.53 \pm 0.245 \\
(t=2.18)^{*}\end{array}$ & 1 & - & - \\
\hline Novograd- & $\begin{array}{c}0.34 \pm 0.271 \\
(t=1.25)\end{array}$ & $\begin{array}{c}0.50 \pm 0.250 \\
(t=2.00)\end{array}$ & $\begin{array}{c}\mathbf{0 . 8 9} \pm 0.133 \\
(t=6.65)^{* *}\end{array}$ & 1 & - \\
\hline Volynskij & $\begin{array}{c}\mathbf{0 . 9 8} \pm 0.055 \\
(t=17.9)^{* *}\end{array}$ & $\begin{array}{c}\mathbf{0 . 9 6} \pm 0.088 \\
(t=10.97)^{* *}\end{array}$ & $\begin{array}{c}-0.03 \pm 0.316 \\
(t=0.09)\end{array}$ & $\begin{array}{c}0.29 \pm 0.303 \\
(t=0.95)\end{array}$ & 1 \\
\hline Teteriv & $\begin{array}{c}\mathbf{0 . 8 9} \pm 0.131 \\
(t=9.81)^{* *}\end{array}$ & $\begin{array}{c}\mathbf{0 . 7 7} \pm 0.184 \\
(t=4.17)^{* *}\end{array}$ & $\begin{array}{c}0.42 \pm 0.262 \\
(t=1.60)\end{array}$ & $\begin{array}{c}0.58 \pm 0.235 \\
(t=2.47)^{*}\end{array}$ & $\begin{array}{c}\mathbf{0 . 9 2} \pm 0.127 \\
(t=7.21)^{* *}\end{array}$ \\
\hline
\end{tabular}

Notes: * italic, significant at $P<0.05$; ** - bold, significant at $P<0.01$.

The correlation was significant at $P<0.01$ for epy hydrothermal index in Olevsk with those in Ovruch, Teteriv, and Zhytomyr. Novograd-Volynskij and Korosten was another pair of meteorological stations with significant correlation (see Table 6). Precipitation data for some years were missed in the databases of the last two meteorological stations. Therefore, the values of the hydrothermal index for 2005-2018 were averaged for Olevsk, Ovruch, Teteriv, and Zhytomyr (Fig. 7).

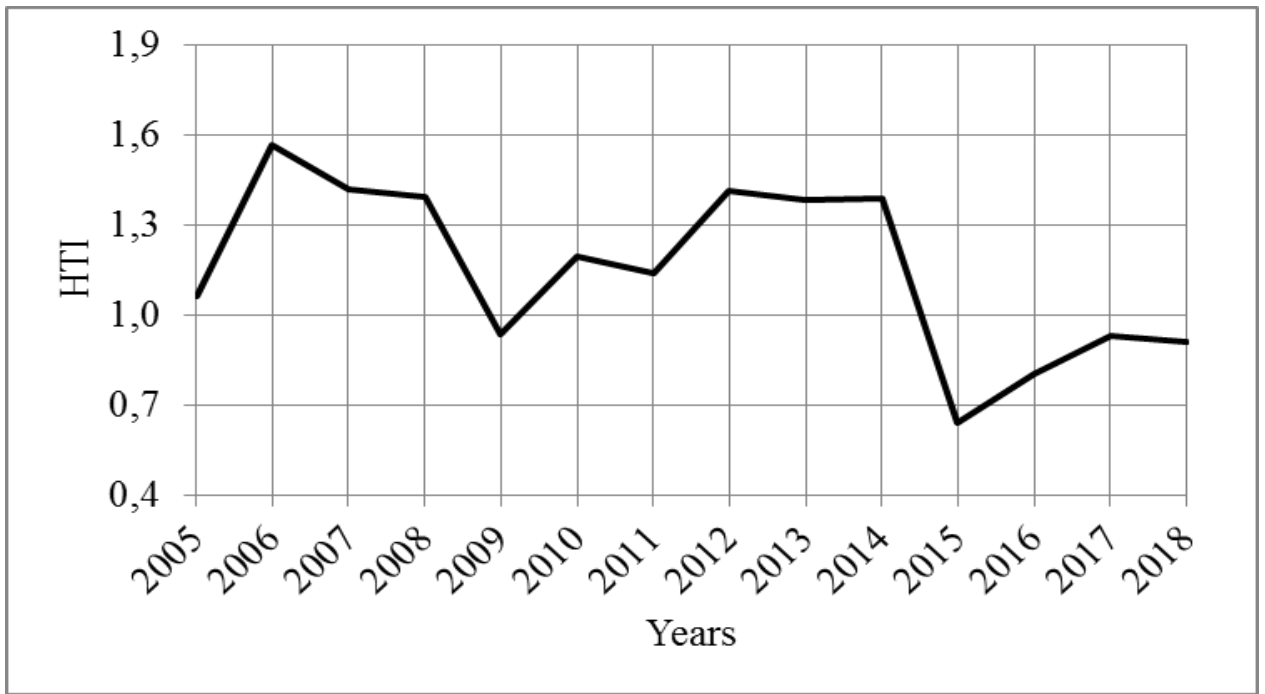

Fig. 7 - Hydrothermal index dynamics for 2005- 2018 growing seasons

(averaged for four meteorological stations of Zhytomyr Polissya - Olevsk, Ovruch, Teteriv and Zhytomyr)

Three minimums of the hydrothermal index can be seen for recent 14 years (in 2005, 2009 and 2015), and every next minimum is less than the previous one (Fig. 7). After the first minimum in 2005 (HTI = 1.01), hydrothermal index value returned to "standard" for Polissya for 2006-2008. After the second minimum in 2009 (HTI = 0.94), this index stayed on the level for Forest-steppe "standard" for two years and for the next three years was in the lower level of "standard" for Polissya (1.38-1.41) followed by drastically fell in 2015 to the HTI value below "standard" for Forest-steppe $(\mathrm{HTI}=0.64)$. Despite the increase the HTI value in subsequent years, it remained at the Steppe "standard" level up to now (see Fig. 7). Such decrease in HTI in Polissya is unfavorable for forest trees, which are adapted to the high humidity of air and soil (Vorobyov 1953). 
Conclusions. In 2005-2018 an average annual and growing season air temperature has increased in all parts of the Central Polissya. Such growth was greater in the southern part of the region. For 2005-2008 significant correlation of annual and growing season air temperature was proved for most of the meteorological stations.

At temperature conditions until 2009, multivoltine bark beetles were possible to develop only one full generation. Two bark beetle generations development was possible in the vicinity of 5 meteorological stations in 2010, three meteorological stations in 2012, two meteorological stations in 2015, one meteorological station in 2016, and five meteorological stations in 2018.

Decrease of precipitation and increase of air temperature brought to decrease an average hydrothermal index value, which fell to the Forest-steppe "standard" in 2005 and 2009 and to the Steppe "standard" in 2015. Such a decrease is unfavorable for forest trees, which are adapted to the high humidity of air and soil.

\section{ПОСИЛАННЯ - REFERENCES}

Andreieva, O. Y. and Goychuk, A. F. 2018. Spread of Scots pine stands decline in Korostyshiv Forest Enterprise. Lisivnytstvo i ahrolisomelioratsiya [Forestry and Forest Melioration], 132: 148-154.

Andreieva, O. Y., Guzii, A.I., Vyshnevskyi, A. V. 2018. Poshyrennya oseredkiv masovoho rozmnozhennya koroyidiv u sosnovykh nasadzhennyakh Rivnenskogo Polissya [Spread of bark beetles foci in pine stands of Rivne Polissya]. Naukovyy visnyk NLTU Ukrayiny [Scientific Bulletin of UNFU], 28(3): 14-17. https://doi.org/10.15421/40280302 (in Ukrainian)

Atramentova, L. A. and Utevskaya, O. M. 2008. Statisticheskiye metody v biologii [Statistical methods in biology]. Gorlovka, 148 p. (in Russian).

Balabukh, V. O., Zhyla, S. M., Orlov, O. O., Yaremchenko O. A. 2013. Vrazlyvi ekosystemy Poliskoho pryrodnoho zapovidnyka ta yoho okolyts $\mathrm{v}$ umovakh hlobalnoho poteplinnya: problemy ta shlyakhy vyrishennya [Vulnerable ecosystems of Polissya natural reserve and its environs in conditions of global warming: problems and ways of solving]. Kyiv, NVP Interservis Ltd., 92 p. (in Ukrainian).

Borodavka, V. O., Getmanchuk, A. I., Kychyljuk, O. V., Vojtjuk, V. P. 2016. Patologichni procesy u vsyhajuchyh sosnovyh nasadzhennjah Volynskogo Polissja [Pathological processes of declining pine stands in Volyn Polissya]. [Electronic resource]. Naukovyj visnyk NUBiP Ukrainy. Serija Lisivnyctvo ta dekoratyvne sadivnyctvo [Scientific Bulletin of NULES of Ukraine. Series: Forestry and decorative gardening], 238: 102-118. Available from: http://nbuv.gov.ua/UJRN/nvnau_lis_2016_238_14 (last accessed date 01.10.2018) (in Ukrainian).

Dibrov, B. I. 1969. Ahroklimatychnyy dovidnyk po Zhytomyrskiy oblasti. [Agroclimatic Reference book in Zhytomyr region]. Vernander, N. B. (Ed). Kyiv, Urozhay, 59 p. (in Ukrainian).

Getmanchuk, A., Kychylyuk, O., Voytyuk, V., Borodavka, V. 2017. Rehionalni zminy klimatu yak prychyna hostrykh vsykhan sosnyakiv Volynskoho Polissya [Regional climate changes as primary cause of pine stands decline in Volyn Polissya]. Naukovyy visnyk NLTU Ukrayiny [Scientific Bulletin of UNFU], 27(1): 120-124 (in Ukrainian).

Lieutier, F., Mendel, Z., Faccoli, M. 2016. Bark beetles of Mediterranean conifers. In: Paine T., Lieutier F. (Eds) Insects and Diseases of Mediterranean Forest Systems. Springer, Cham. doi: 10.1007/978-3-319-24744-1_6

Meshkova, V. L. 2009. Sezonnoye razvitiye khvoyelistogryzushchikh nasekomykh [Seasonal development of foliage browsing insects]. Kharkiv, Planeta-print, 396 p. (in Russian).

Meshkova, V. L. and Borysenko, O. I. 2017. Dynamics of pine engraver beetle-caused forest decline in Teterivske Forestry Enterprise. Lisivnytstvo i ahrolisomelioratsiya [Forestry and Forest Melioration], 131: 171-178.

Meshkova, V. L. and Borysenko, O. I. 2018. Prediction for bark beetles caused desiccation of pine stands. Lisivnytstvo i ahrolisomelioratsiya [Forestry and Forest Melioration], 132. 155-161.

Meshkova, V. L., Kochetova, A. I., Zinchenko, O. V. 2015. Verkhivkovyy koroyid Ips acuminatus (Gyllenhal, 1827): Insecta: Coleoptera: Scolytinae u Pivnichno-Skhidnomu Stepu Ukrayiny [The pine engraver beetle Ips acuminatus (Gyllenhal, 1827) (Coleoptera: Curculionidae: Scolytinae) in the NorthEastern Steppe of Ukraine]. The Kharkov Entomol. Soc. Gaz., 23(2): 64-69 (in Ukrainian).

Meshkova, V. L., Kochetova, A. I., Zinchenko, O. V., Skrylnik, Yu. Ye. 2017. Biology of multivoltine bark beetles species (Coleoptera: Scolytinae) in the North-Eastern Steppe of the Ukraine. The Bulletin of Kharkiv National Agrarian University. Series: Phytopathology and Entomology, 1-2: 117-124.

Pineau, X., David, G., Peter, Z., Sallé, A., Baude, M., Lieutier, F., Jactel, H. 2017. Effect of temperature on the reproductive success, developmental rate and brood characteristics of Ips sexdentatus (Boern.). Agricultural and Forest Entomology, 19(1): 23-33.

Sazonov, A. A., Kukhta, V. N., Tapchevskaya, V. A. 2017. Vspyshka massovogo razmnozheniya vershinnogo koroyeda (Ips acuminatus (Gyllenhal, 1827), Scolytinae, Coleoptera) v lesakh Belorusskogo Poles'ya [Outbreak of mass reproduction of pine engraver beetle (Ips acuminatus (Gyllenhal, 1827), Scolytinae, Coleoptera) in the forests of the 


\section{ЛICIВНИЦТВО I АГРОЛІСОМЕЛІОРАЦІЯ - FORESTRY AND FOREST МЕLIORATION}

2018. Вип. 133 - 2018. Iss. 133

Byelorussian Polesie]. In: Itogi i perspektiví razvitiya entomologii v Vostochnoy Yevrope: sbornik statey II Mezhdunarodnoy nauchno-prakticheskoy konferentsii, September 6-8, 2017, Minsk [Results and prospects of development of entomology in Eastern Europe: a collection of articles of the II International Scientific and Practical conference, September 6-8, 2017, Minsk]. Borodin, O. I., Tsinkevich, V. A., Varaksin A. N. (Eds.), p. $366-378$ (in Russian).

Selyaninov, G. T. 1937. Metodika selskokhozyaystvennoy kharakteristiki klimata [Methodology of Agricultural Climate Characteristics]. Mirovoy agroklimaticheskiy spravochnik [World Agro-climatic reference book]. Leningrad; Moscow, p. 5-29 (in Russian).

Shvydenko, A.Z., Buksha, I. F., Krakovskaya, S. V. 2018. Urazlyvist lisiv Ukrayiny do zminy klimatu [The vulnerability of Ukraine's forests to climate change]. Kyiv, Nika-Center, 184 p. (in Ukrainian).

Siitonen, J. 2014. Ips acuminatus kills pines in southern Finland. Silva Fennica, 48 (4), article id 1145.7 p. http://dx.doi.org/10.14214/sf.1145.

Vorobyov, D. V. 1953. Tipy lesa yevropeyskoy chasti SSSR. [Forest types of the European part of the USSR]. Kyiv, Izdatelstvo AN USSR, 450 p. (in Russian).

Vyshnevskyi, A. V. and Turko, V. M. 2018. The spread of diseases in Volyn region forests. Scientific Bulletin of UNFU, 28(1): 51-54. https://doi.org/10.15421/40280110.

Андресва О. Ю.

КЛІМАТИЧНІ ЧИННИКИ, ЩО ВПЛИВАЮТЬ НА УРАЗЛИВІСТЬ СОСНИ ЗВИЧАЙНОЇ ДО НАПАДІВ КОРӦ̈ДІВ У ЦЕНТРАЛЬНОМУ ПОЛІССІ

Житомирський національний агроекологічний університет

Метою досліджень було оцінити зміни кліматичних чинників у Центральному Поліссі, які можуть сприяти підвищенню уразливості сосни звичайної до нападів короїдів та збільшенню щільності їхніх популяцій. У $2005-$ 2018 рр. збільшилася середня температура повітря за рік і вегетаційний період, особливо у південній частині регіону. За температурними умовами до 2009 р. мультивольтинні короїди були спроможні завершити лише одну повну генерацію. Температурні умови в насадженнях сосни звичайної в районі 5 метеостанцій у 2010 р., трьох метеостанцій у 2012 р., двох метеостанцій у 2015 р., однієї метеостанції в 2016 р. та п’яти метеостанцій у 2018 р. були сприятливими для розвитку двох поколінь короїда. Середня кількість опадів за вегетаційний період 2005-2018 pр. поступалася багаторічним даним усіх проаналізованих метеостанцій, крім Олевська. Середнє значення гідротермічного коефіцієнта (ГТК) за Г. Т. Селяніновим зменшилося до «норми» Лісостепу у 2005 i 2009 рр. та до «норми» Степу у 2015 р. Таке зменшення не є сприятливим для лісових порід, адаптованих до високої вологості повітря та грунту.

К л ю ч о в і с л о в а : всихання лісу, короїди, температура повітря, опади, гідротермічний коефіцієнт (ГТК) за Г. Т. Селяніновим.

Андреева Е. Ю.

КЛИМАТИЧЕСКИЕ ФАКТОРЫ, ВЛИЯЮЩИЕ НА УЯЗВИМОСТЬ СОСНЫ ОБЫКНОВЕННОЙ К НАПАДЕНИЮ КОРОЕДОВ В ЦЕНТРАЛЬНОМ ПОЛЕСЬЕ

Житомирский национальный агроэкологический университет

Целью исследований было оценить изменения климатических факторов в Центральном Полесье, которые могут способствовать повышению уязвимости сосны обыкновенной к нападению короедов и увеличению плотности их популяций. У 2005-2018 возросла средняя температура воздуха за год и вегетационный период, особенно в южной части региона. По температурным условиям до 2009 г. мультивольтинные короеды были способны завершить развитие лишь одной полной генерации. Температурные условия в сосновых насаждениях в окрестностях 5 метеорологических станций в 2010 г., трех метеорологических станций в 2012 г., двух метеорологических станций в 2015 г., одной метеорологической станции в 2016 г. и пяти метеорологических станций в 2018 г. были благоприятными для развития двух поколений короедов. Среднее количество осадков за вегетационный период 2005-2018 гг. было меньшим, чем по многолетним данным всех проанализированных метеостанций, кроме Олевска. Среднее значение гидротермического коэффициента (ГТК) по Г. Т. Селянинову уменьшилось до «нормы» Лесостепи в 2005 и 2009 гг. и до «нормы» Степи в 2015 г. Такое уменьшение неблагоприятно для лесных пород, адаптированных к высокой влажности воздуха и почвы.

Ключевы е слова: усыхание леса, короеды, температура воздуха, осадки, гидротермический коэффициент (ГТК) по Г. Т. Селянинову.

Одержано редколегією 08.10.2018

E-mail: andreeva-lena15@ukr.net 